\title{
Adsorption of Rhodamine B from Aqueous Solution by Goat Manure Biochar: Kinetics, Isotherms, and Thermodynamic Studies
}

\author{
Yixin Lu' ${ }^{1,2}$, Jiao Chen ${ }^{1 *}$, Li Zhao ${ }^{1}$, Zheng Zhou ${ }^{1}$, Cheng Qiu${ }^{1}$, Qianglin Li ${ }^{1}$ \\ ${ }^{1}$ College of Architectural and Environmental Engineering, Chengdu Technological University, Chengdu, China \\ ${ }^{2}$ Faculty of Geosciences and Environmental Engineering, Southwest Jiaotong University, Chengdu, China
}

Received: 13 June 2019

Accepted: 8 September 2019

\begin{abstract}
Biochar was prepared by pyrolyzing goat manure at $600^{\circ} \mathrm{C}$ (GMB600) and used as an adsorbent for the removal of Rhodamine $\mathrm{B}(\mathrm{RhB})$ from aqueous solution. The structure and properties of GMB600 were characterized by elemental analysis, BET, SEM and FTIR. The effects of solution $\mathrm{pH}$, biochar dosage, contact time, initial $\mathrm{RhB}$ concentration and temperature on the adsorption behaviors were investigated by batch experiments, which were further used to preliminarily discuss the adsorption mechanism. Results showed that the adsorption equilibrium could attain in $150 \mathrm{~min}$ and the $\mathrm{RhB}$ removal rate could reach $96.5 \%$ under the conditions of solution $\mathrm{pH} 5.0$, GMB600 dosage of $0.4 \mathrm{~g} / \mathrm{L}$, initial $\mathrm{RhB}$ concentration of $20 \mathrm{mg} / \mathrm{L}$ and temperature of $25^{\circ} \mathrm{C}$. The adsorption behavior of $\mathrm{RhB}$ onto GMB600 followed the pseudo second-order kinetic model, and the adsorption isotherm was better fitted with the Freundlich model. Thermodynamic parameters such as Gibbs free energy change $\left(\Delta G^{\circ}\right)$, enthalpy change $\left(\Delta H^{\circ}\right)$ and entropy change $\left(\Delta S^{\circ}\right)$ indicated that the adsorption of RhB onto GMB600 was a spontaneous and endothermic process with increased entropy. FTIR analysis showed that the oxygen-containing functional groups on GMB600 provided RhB with abundant adsorption sites, and the adsorption mechanism was possibly attributable to the hydrogen bond and $\pi-\pi$ interactions between RhB and GMB600.
\end{abstract}

Keywords: biochar, goat manure, Rhodamine B, adsorption kinetics, isotherms, thermodynamics

\section{Introduction}

Rhodamine B (RhB) is a synthetic organic dye widely used in textile, paper-making, leather manufacture, stained glasswork, the cosmetics industry and many other industries due to its high tinting strength, bright color and high stability $[1$, 2]. These industries produce a great amount of $\mathrm{RhB}$ dye wastewater, with the characteristics of high colority, poor biodegradability and heavy toxicity [3]. The traditional biological method hardly meets the emission requirements, while directly draining into water would cause serious threats to the environment and human health. Previous experimental studies have 
proven that $\mathrm{RhB}$ can lead to carcinogenic, teratogenic and mutagenic effects when the hazardous substance irritates eyes or skin, which causes severe harm to the health of human beings and animals [4, 5]. Considering this, it is especially important to explore efficient and economical ways for $\mathrm{RhB}$ wastewater treatment.

At present, researchers have tried a number of methods to remove $\mathrm{RhB}$ dye from aqueous solution, such as adsorption $[6,7]$, the electro-Fenton process [8], photodegradation [9], sonochemical degradation [10] and membrane separation [11]. Among them, adsorption has been regarded as one of the most potential methods and widely favored by researchers because of its advantages such as convenient operating conditions, good treatment effects and an abundant source of raw materials. A variety of materials including bentonite [12], montmorillonite [13], activated carbon [14], as well as many other materials prepared by agricultural bio-wastes $[15,16]$ have been used as adsorbents for $\mathrm{RhB}$ removal from aqueous solutions. Moreover, it has become a research hotspot in recent years for exploring new adsorbents featuring high-efficiency, low-cost and non-secondary pollution.

Biochar is a type of carbon-containing product produced by biomass residual body through hightemperature pyrolysis in an oxygen-limited or oxygenfree state [17]. Compared with commercial activated carbon, biochar has a large specific area and good adsorption capacity as well. Moreover, it is much cheaper than activated carbon owing to its simple preparation process [18]. In addition, biochar can also effectively improve the physical and chemical properties of soil and further increase crop production [19]. Therefore, reports concerning the use of bio-char to absorb organic dyes have been increasing recently. In previous studies, straw [20, 21], bark [22], water hyacinth [23] and some other plant source materials were used to prepare biochar. China is one of the largest farming countries with an enormous amount of animal manure produced by livestock and poultry farming, which would cause great pressure on the environment if these wastes could not be effectively treated or recycled. Nevertheless, studies on the preparation of biochar from animal manure source materials for $\mathrm{RhB}$ dye adsorption have rarely been reported. The adsorption mechanism of $\mathrm{RhB}$ dye onto animal manure biochar is not yetThe objective of this study was to investigate the feasibility of biochar prepared from goat manure as a novel adsorbent for the removal of $\mathrm{RhB}$ dye from aqueous solutions. The effects of solution $\mathrm{pH}$, biochar dosage, contact time, initial $\mathrm{RhB}$ concentration and temperature on the adsorption performance were studied. Based on this, the mechanism of RhB adsorption by goat manure biochar was further analyzed via kinetic, isothermal and thermodynamic models. The results would provide a theoretical basis for the application of goat manure biochar in $\mathrm{RhB}$ wastewater treatment and explore a new way for the resource utilization of goat manure.

\section{Experimental}

\author{
RhB Dye Solution
}

$\mathrm{RhB}$, molecular formula $\mathrm{C}_{28} \mathrm{H}_{31} \mathrm{ClN}_{2} \mathrm{O}_{3}$, also known as basic rose red or brilliant pink $\mathrm{B}$, was purchased from Aladdin Chemical Reagent Co. Ltd. The structural formula of $\mathrm{RhB}$ is shown in Fig. 1. The stock solution of $\mathrm{RhB}(1000 \mathrm{mg} / \mathrm{L})$ was prepared in deionized water, while fresh dilutions of the desired $\mathrm{RhB}$ concentrations were prepared according to the experimental requirement. The $\mathrm{pH}$ value of $\mathrm{RhB}$ solution was adjusted by adding $0.1 \mathrm{~mol} / \mathrm{L} \mathrm{HCl}$ or $0.1 \mathrm{~mol} / \mathrm{L} \mathrm{NaOH}$. The chemical reagents used in the experiment were all analytically pure.

\section{Preparation of Goat Manure Biochar}

Goat manure was collected from a farm in Ya'an city, Sichuan Province of China. The goat manure was air-dried under ambient conditions and ground to pass a 80 mesh sieve. The ground goat manure was put into a crucible, compacted and covered well. Then it was heated to $600^{\circ} \mathrm{C}$ in a muffle furnace at a $15^{\circ} \mathrm{C}$ per minute gradient and kept at constant temperature for $150 \mathrm{~min}$. After the pyrolysis products cooled to room temperature, $20 \mathrm{~mL}$ of $\mathrm{HCl}(1.0 \mathrm{~mol} / \mathrm{L})$ was added to each and every 1 gram of the pyrolysis products and the solution was shaken at $150 \mathrm{rpm}$ for $30 \mathrm{~min}$. The operation was repeated 3 times to remove ash from the pyrolysis product. After filtration, the product was washed to neutral with deionized water, oven-dried at $105^{\circ} \mathrm{C}$ for $48 \mathrm{~h}$ and then passed through a 100 mesh sieve. The goat manure biochar (GMB600) was successfully prepared and then packed in a sealing bag for later use.

\section{Adsorption Experiments}

The effect of initial solution $\mathrm{pH}$ on $\mathrm{RhB}$ removal was studied over the $\mathrm{pH}$ range of 3.0 9.0 with $0.5 \mathrm{~g} / \mathrm{L}$ of GMB600 for $300 \mathrm{~min}$ in a RhB solution of $20 \mathrm{mg} / \mathrm{L}$ concentration at $25^{\circ} \mathrm{C}$. The effect of biochar dosage on $\mathrm{RhB}$ removal was investigated with different GMB600 dosage $(0.2 \sim 2.0 \mathrm{~g} / \mathrm{L})$ in a $\mathrm{RhB}$ solution of $20 \mathrm{mg} / \mathrm{L}, \mathrm{pH}$ 5.0 and shaken for $300 \mathrm{~min}$ at $25^{\circ} \mathrm{C}$. The effect of contact time on RhB removal was investigated with GMB600 in a $\mathrm{RhB}$ solution of $20 \mathrm{mg} / \mathrm{L}, \mathrm{pH} 5.0$ and shaken for<smiles>CCN(CC)c1ccc2c(-c3ccccc3C(=O)O)c3ccc(=[N+](CC)CC)cc-3oc2c1</smiles>

Fig. 1. Structural formula of RhB. 
different adsorption time $(5 \sim 500 \mathrm{~min})$ at $25^{\circ} \mathrm{C}$. The effect of initial $\mathrm{RhB}$ concentration and temperature on $\mathrm{RhB}$ removal was investigated by shaking $0.4 \mathrm{~g} / \mathrm{L}$ of GMB600 for $150 \mathrm{~min}$ in $\mathrm{RhB}$ solution of different initial concentrations $(10 \sim 100 \mathrm{mg} / \mathrm{L}), \mathrm{pH} 5.0$ at $298 \mathrm{~K}$, $308 \mathrm{~K}$ and $318 \mathrm{~K}$, respectively.

All the above experiments were conducted in a gas bath homoiothermy shaker at $200 \mathrm{rpm}$. After adsorption, the suspensions were centrifuged at $4000 \mathrm{rpm}$ for 5 minutes and then the prepared samples for analyses $(4 \mathrm{~mL})$ were filtered in a $0.45 \mu \mathrm{m}$ membrane.

\section{Analysis Methods}

The contents of $\mathrm{C}, \mathrm{H}, \mathrm{N}$ and $\mathrm{O}$ of GMB600 were tested by elemental analyzer (VARIO EL cube, Elementar, German). The specific surface area, total pore volume and average pore diameter of GMB600 were tested using BET analysis (NOVA4000e, Quantachrome, America). The surface morphology of GMB600 was analyzed by a field emission scanning electron microscope (SUPRA40, ZEISS, German). The functional group on the surface of GMB600 was determined by a Fourier infrared spectrometer (FTIR Spectrum100, Perkin Elmer, America). The concentration of $\mathrm{RhB}$ was measured at $\lambda_{\text {max }} 554 \mathrm{~nm}$ by UV-Vis spectrophotometry (UV-1800PC, HITACHI, Japan). The mean data value obtained after three parallel tests was analyzed and fitted by origin 9.0.

The RhB removal rate $(R, \%)$ and amount of $\mathrm{RhB}$ adsorbed by GMB600 $\left(q_{e}, \mathrm{mg} / \mathrm{g}\right)$ at equilibrium were calculated by the following equations:

$$
\begin{gathered}
R=\frac{C_{0}-C_{\mathrm{e}}}{C_{0}} \times 100 \% \\
q_{\mathrm{e}}=\frac{\left.C_{0}-C_{\mathrm{e}}\right) V}{m}
\end{gathered}
$$

...where $C_{0}$ and $C_{\mathrm{e}}$ are the initial and equilibrium concentrations of $\mathrm{RhB}$ solution $(\mathrm{mg} / \mathrm{L}), V$ is the volume of RhB solution (mL) and $m$ is the mass of GMB600 (g).

\section{Results and Discussion}

\section{Biochar Properties}

The elementary composition of GMB600 is shown in Table 1. As seen, GMB600 contained a lot of $\mathrm{C}$ and a little bit of $\mathrm{H}$ and $\mathrm{N}$. In general, the aromaticity and polarity of adsorption materials could be judged according to the ratio of $\mathrm{H} / \mathrm{C}$ and $\mathrm{O} / \mathrm{C}$. The aromaticity of biochar decreased with the increase of $\mathrm{H} / \mathrm{C}$ ratio, and the polarity of biochar increased with the increase of $\mathrm{O} / \mathrm{C}$ ratio. The previous studies showed that the biochar contained concentrated aromatic rings when the $\mathrm{H} / \mathrm{C}$ ratio was less than 0.6 and the half-life cycle of biochar was estimated at more than 1000 years
Table1. Elemental composition and BET analysis of GMB600.

\begin{tabular}{|c|c|}
\hline Property & GMB600 \\
\hline Ash content (\%) & 18.37 \\
\hline $\mathrm{C}(\%)$ & 63.25 \\
\hline $\mathrm{H}(\%)$ & 2.21 \\
\hline $\mathrm{O}(\%)$ & 12.09 \\
\hline $\mathrm{N}(\%)$ & 2.49 \\
\hline $\mathrm{H} / \mathrm{C}$ & 0.035 \\
\hline $\mathrm{O} / \mathrm{C}$ & 0.191 \\
\hline $\mathrm{pH}$ & 7.0 \\
\hline Specific surface area $\left(\mathrm{m}^{2} / \mathrm{g}\right)$ & 181.76 \\
\hline Total pore volume $\left(\mathrm{cm}^{3} / \mathrm{g}\right)$ & 0.245 \\
\hline Average pore diameter $(\mathrm{nm})$ & 11.91 \\
\hline
\end{tabular}

when the $\mathrm{O} / \mathrm{C}$ ratio was less than $2.0[24,25]$. In this study, the ratio of $\mathrm{H} / \mathrm{C}$ and $\mathrm{O} / \mathrm{C}$ was 0.035 and 0.191 respectively, indicating that GMB600 was of relatively high aromaticity and stability.

The SEM of GMB600 is given in Fig. 2. The surface of GMB600 was rough and uneven and its interior was loose and porous, with large specific surface area and rich pore structure. Additionally, according to the results of BET analysis shown in Table 1, the specific surface area and total pore volume of GMB600 were respectively $181.76 \mathrm{~m}^{2} / \mathrm{g}$ and $0.245 \mathrm{~cm}^{3} / \mathrm{g}$, which would provide favorable conditions for $\mathrm{RhB}$ adsorption onto the biochar.

\section{Effect of Operational Variables on RhB Adsorption}

\section{Effect of Initial Solution $p H$}

$\mathrm{pH}$ value is an important factor affecting adsorption performance, since it can alter not only the charge or

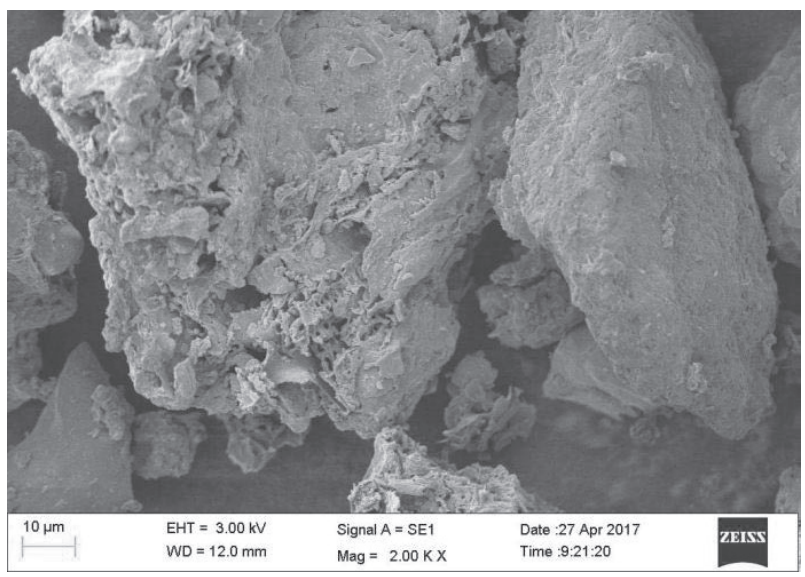

Fig. 2. Scanning electron microscope of GMB600. 
species of adsorbate but also the surface properties of the adsorbent. The effect of initial solution $\mathrm{pH}$ on RhB adsorption by GMB600 is shown in Fig. 3a). As seen, the removal rate of $\mathrm{RhB}$ was over $97 \%$ in the $\mathrm{pH}$ of 4.0 to 5.0. Under acidic conditions, $\mathrm{RhB}$ mainly existed in the form of quaternary ammonium cation and molecule and the surface functional groups of biochar protonated [26]. So it was beneficial to obtain better adsorption rates via ion-exchange within the above $\mathrm{pH}$ range. When the $\mathrm{pH}$ value was 3.0 , the surplus $\mathrm{H}^{+}$in the solution began to compete with $\mathrm{RhB}$ for the surface adsorption sites of biochar, resulting in a decrease in the amount of $\mathrm{RhB}$ adsorbed.

When the $\mathrm{pH}$ value was higher than 5.0, the removal rate of $\mathrm{RhB}$ onto GMB600 decreased with the increase of $\mathrm{pH}$, and it was only $67.29 \%$ when the $\mathrm{pH}$ value increased to 10.0. Since the occurrence of carboxyl ionization in $\mathrm{RhB}$ in alkaline condition, the quaternary ammonium cation and carboxyl anions coexisted in the solution, causing polymerization and precipitation and leading to the blockade of the channel where $\mathrm{RhB}$ entering into the micro-pores of biochar [27, 28]. In addition, the excessive $\mathrm{OH}^{-}$in the solution was able to compete for the surface adsorption sites of biochar with $\mathrm{RhB}$, leading to a significant decrease in $\mathrm{RhB}$ removal rate.

\section{Effect of Biochar Dosage}

The effect of biochar dosage on RhB adsorption is shown in Fig. 3b). As illustrated in Fig. 3b), the removal rate of $\mathrm{RhB}$ increased with the increase of GMB600 dosage and then approached to a flat because the increase of adsorbent dosage could provide a larger specific surface and more adsorption sites for RhB. In contrast, the amount of $\mathrm{RhB}$ adsorbed by unit mass of GMB600 decreased with the increase of biochar dosage. A decrease of $q_{e}$ from 77.059 to $9.979 \mathrm{mg} / \mathrm{g}$ was observed when the GMB600 dosage increased from 0.2 to $2.0 \mathrm{~g} / \mathrm{L}$. The reason could be as follows. In the case of limited adsorbate, increasing biochar dosage could lead to a surplus of biochar, in turn resulting in a decrease of RhB adsorbed by unit mass of GMB600. This regulation was similar to the result of Aljeboree's research in crystal violet dye adsorption by activated carbon [29]. Taking both adsorption efficiency and economy into consideration, the optimal GMB600 dosage for the subsequent experiments was determined to be $0.4 \mathrm{~g} / \mathrm{L}$. Under this dosage condition, the removal rate of $\mathrm{RhB}$ was $96.89 \%$ and the $q_{e}$ was $48.443 \mathrm{mg} / \mathrm{g}$.

\section{Effect of Contact Time}

Fig. 3c) shows the effect of contact time on adsorption performance of GMB600. As can be seen from Fig. 3c), the adsorption process of RhB onto GMB600 could be divided into three phases, namely the rapid adsorption phase (phase I: $0 \sim 60 \mathrm{~min}$ ), the slow diffusion phase (phase II: $60 \sim 120 \mathrm{~min}$ ) and the adsorption equilibrium phase (phase III: 120 500 min).

In phase I, the adsorption sites of GMB600 were sufficient, $\mathrm{RhB}$ could rapidly occupy these sites under the action of mass transfer driving force and thus it could be adsorbed by GMB600 quickly. The RhB removal rate reached $86.25 \%$ in this phase. In phase II, the adsorption sites of GMB600 and the residual
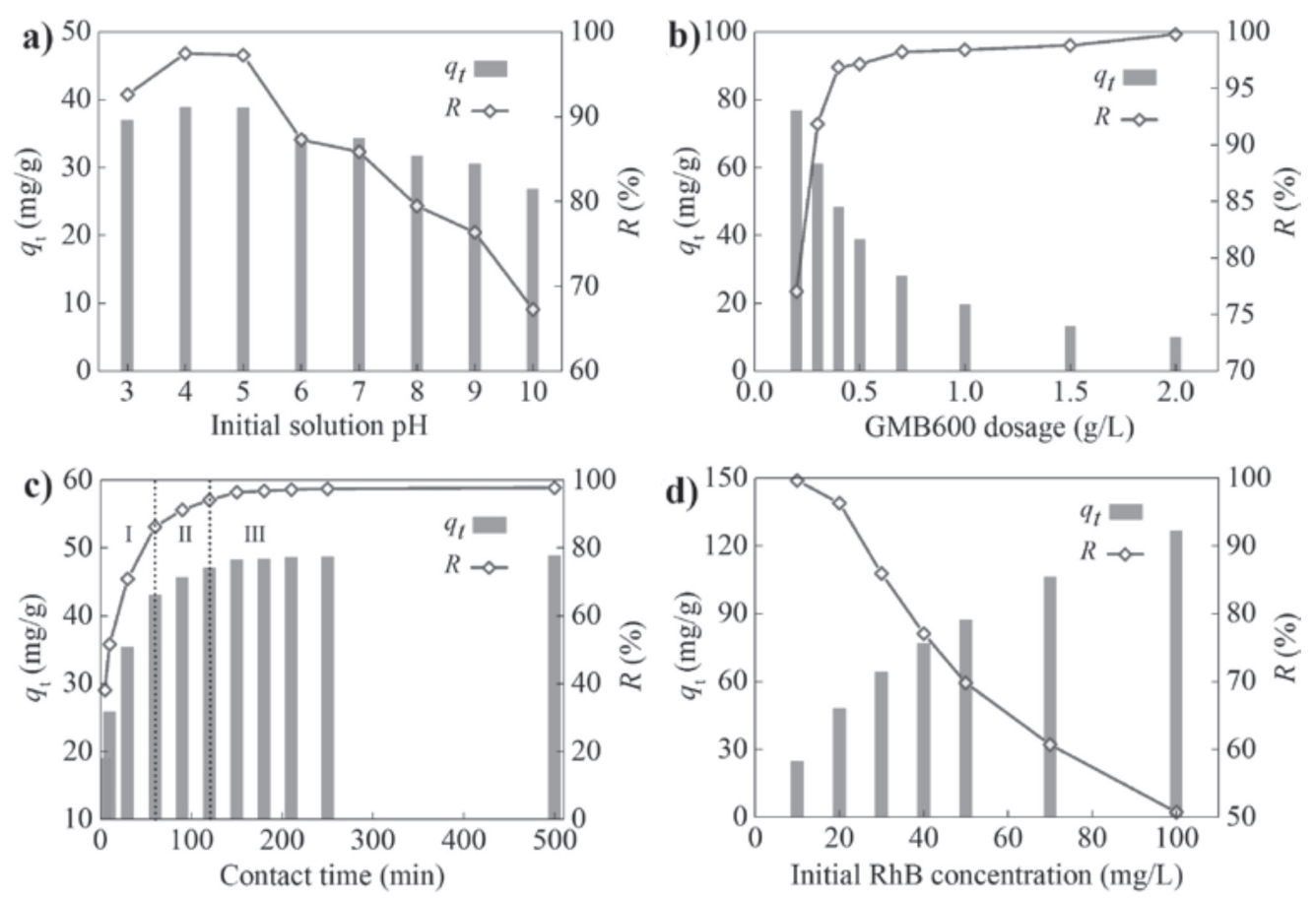

Fig. 3. Effect of initial solution pH a), GMB600 dosage b), contact time c) and initial RhB concentration d) on adsorption performance. 
$\mathrm{RhB}$ in the solution were gradually reduced as the extension of contact time, resulting in a decrease in $\mathrm{RhB}$ concentration gradient between the GMB600 and solution. Thus, the adsorption rate of $\mathrm{RhB}$ went down with the reduction of mass transfer driving force. In phase III, the adsorption amount of RhB was almost unchanged as time prolonged. The adsorption of GMB600 for $\mathrm{RhB}$ reached equilibrium at $150 \mathrm{~min}$, and the $\mathrm{RhB}$ removal rate reached $96.5 \%$. Therefore, the optimal contact time for the subsequent experiments was determined to be $150 \mathrm{~min}$.

\section{Effect of Initial RhB Concentration}

The adsorption efficiency of GMB600 under different initial $\mathrm{RhB}$ concentrations is depicted in Fig. 3d). The results showed that, with the increase of the $\mathrm{RhB}$ initial concentration from $10 \mathrm{mg} / \mathrm{L}$ to $100 \mathrm{mg} / \mathrm{L}$, the equilibrium adsorption amount of $\mathrm{RhB}$ increased from $24.652 \mathrm{mg} / \mathrm{g}$ to $126.828 \mathrm{mg} / \mathrm{g}$, while the corresponding removal rate showed a decrease of from $99.65 \%$ to $50.73 \%$. Analysis suggested that when the initial $\mathrm{RhB}$ concentration increased, the number of $\mathrm{RhB}$ molecules distributed around the biochar increased correspondingly. As such, the RhB concentration gradient between the GMB600 and solution increased, leading to an increase of mass-transfer force so that more RhB could be adsorbed by GMB600. However, since the GMB600 dosage was constant, the adsorption sites for RhB was also limited. With the increase of the initial $\mathrm{RhB}$ concentration, the remaining unadsorbed $\mathrm{RhB}$ in the solution also increased, resulting in the decrease of $\mathrm{RhB}$ removal rate.

\section{Adsorption Kinetics}

To further study the adsorption process of $\mathrm{RhB}$ onto GMB600, the adsorption data were analyzed using four well-known kinetic models, specifically the pseudo first-order model [30] (Eq. 3), pseudo second-order model [31] (Eq. 4), intra-particle diffusion model [32] (Eq. 5) and Elovich model [33] (Eq. 6):

$$
\begin{gathered}
\ln \left(q_{\mathrm{e}}-q_{\mathrm{t}}\right)=\ln q_{\mathrm{e}}-k_{1} t \\
\frac{t}{q_{\mathrm{t}}}=\frac{t}{q_{\mathrm{e}}}+\frac{1}{k_{2} q_{\mathrm{e}}^{2}} \\
q_{\mathrm{t}}=k_{3} t^{0.5}+C \\
q_{\mathrm{t}}=\left(\frac{1}{\beta}\right) \ln (\alpha \cdot \beta)+\left(\frac{1}{\beta}\right) \ln (t)
\end{gathered}
$$

...where $q_{\mathrm{e}}$ is the equilibrium adsorption amount of $\mathrm{RhB}(\mathrm{mg} / \mathrm{g}), q_{\mathrm{t}}$ is the adsorption amount of $\mathrm{RhB}$ at time $t(\mathrm{mg} / \mathrm{g}), k_{1}$ is the pseudo first-order rate constant $\left(\mathrm{min}^{-1}\right), k_{2}$ is the pseudo second-order rate constant $(\mathrm{g} /(\mathrm{mg} \cdot \mathrm{min})), k_{3}$ is the intra-particle diffusion rate constant $\left(\mathrm{mg} /\left(\mathrm{g} \cdot \mathrm{min}^{0.5}\right)\right), C$ is the intercept, $\alpha$ is the initial adsorption rate constant $(\mathrm{g} /(\mathrm{mg} \cdot \mathrm{min})), \beta$ is the desorption rate constant $(\mathrm{g} / \mathrm{mg})$, and $t$ is the contact time (min).

The adsorption kinetics curves of $\mathrm{RhB}$ (20 and $50 \mathrm{mg} / \mathrm{L}$ ) onto GMB600 are given in Fig. 4. The corresponding fitted parameters are listed in Table 2. We can see that the coefficient of determination of the
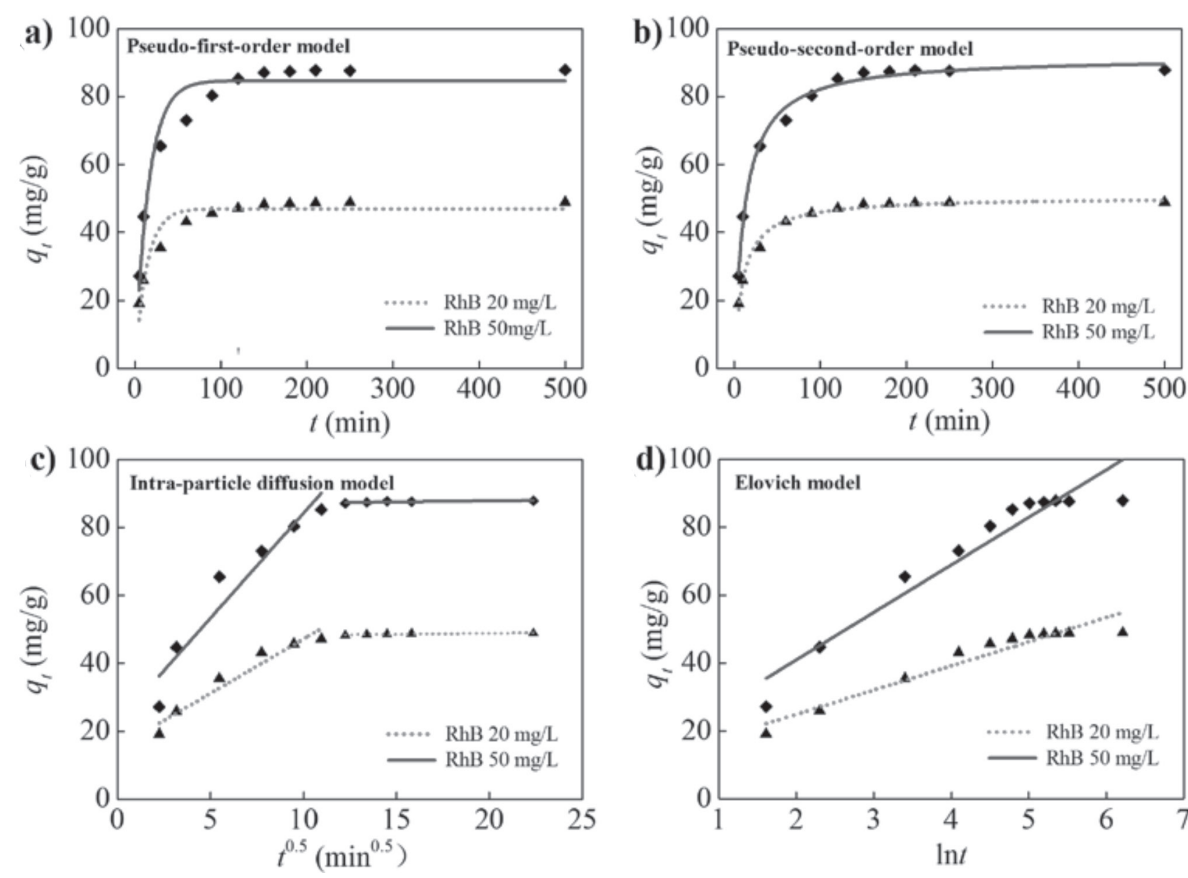

Fig. 4. Adsorption kinetics curves of RhB onto GMB600: a) pseudo first-order model, b) pseudo second-order model, c) intra-particle diffusion model, d) Elovich model. 
Table 2. Fitting parameters of kinetic models for RhB adsorption onto GMB600.

\begin{tabular}{|c|c|c|c|}
\hline \multirow{2}{*}{ Kinetic model } & \multirow{2}{*}{ Parameter } & \multicolumn{2}{|c|}{ Initial $\mathrm{RhB}$ concentration (mg/L) } \\
\hline & & 20 & 50 \\
\hline \multirow{3}{*}{ Pseudo-first-order } & $q_{\mathrm{e}}(\mathrm{mg} / \mathrm{g})$ & 47.026 & 84.628 \\
\hline & $k_{1}\left(\min ^{-1}\right)$ & 0.0725 & 0.0630 \\
\hline & $R^{2}$ & 0.9092 & 0.9369 \\
\hline \multirow{3}{*}{ Pseudo-second-order } & $q_{\mathrm{e}}(\mathrm{mg} / \mathrm{g})$ & 50.436 & 91.645 \\
\hline & $k_{2}(\mathrm{~g} /(\mathrm{mg} \cdot \min ))$ & 0.0021 & 0.0001 \\
\hline & $R^{2}$ & 0.9871 & 0.9913 \\
\hline \multirow{6}{*}{ Intra-particle diffusion } & $C_{1}$ & 15.216 & 22.460 \\
\hline & $k_{3-1}\left(\mathrm{mg} /\left(\mathrm{g} \cdot \min ^{0.5}\right)\right)$ & 3.1960 & 6.1734 \\
\hline & $R^{2}$ & 0.9271 & 0.8985 \\
\hline & $C_{2}$ & 47.745 & 86.645 \\
\hline & $k_{3-2}\left(\mathrm{mg} /\left(\mathrm{g} \cdot \min ^{0.5}\right)\right)$ & 0.0538 & 0.0580 \\
\hline & $R^{2}$ & 0.6674 & 0.4571 \\
\hline \multirow{3}{*}{ Elovich } & $\alpha(\mathrm{g} /(\mathrm{mg} \cdot \min ))$ & 31.662 & 35.286 \\
\hline & $\beta(\mathrm{g} / \mathrm{mg})$ & 0.1402 & 0.0715 \\
\hline & $R^{2}$ & 0.9198 & 0.9158 \\
\hline
\end{tabular}

pseudo second-order model $\left(R^{2}>0.98\right)$ was obviously greater than that of other models. The theoretical $q_{e}$ values obtained from the pseudo second-order model were very close to the experimental $q_{e}$ values, and their relative error was only $3.19 \%$ and $4.32 \%$ respectively. Thus, the pseudo second-order model could fit the adsorption data better than other models.

The pseudo second-order model reflected the whole adsorption process of RhB onto GMB600, such as liquid film diffusion, surface adsorption and intraparticle diffusion [34]. Additionally, according to the fitting results of the intra-particle diffusion model, the whole adsorption process is divided into two stages. The first stage is the diffusion of $\mathrm{RhB}$ across the liquid membrane to the surface of GMB600 (membrane diffusion), and the second stage is the diffusion of $\mathrm{RhB}$ in pores of GMB600 (internal diffusion). The facts that $k_{3-1}>k_{3-2}$ and $C_{1}<C_{2}$ showed that the diffusion of $\mathrm{RhB}$ on the surface of GMB600 was faster, and the main speed-limiting step in the adsorption process was intraparticle diffusion [3]. The Elovich model could describe the diffusion of adsorbents at the adsorption interface, surface activation and deactivation. It is suitable for those reaction processes in which the activation energy varies greatly and can reveal the data irregularity which is ignored by other types of kinetic models. In this research, the coefficient of determination of the Elovich model was less than 0.92 , which is much less than that of the pseudo second-order model. This indicated that the Elovich model was unfit for the adsorbent process in this study.

\section{Adsorption Isotherms}

Adsorption isotherms have been widely applied to evaluate the maximum capacity of adsorbents and to reveal the essence of adsorbate-adsorbent interactions. In the present study, the adsorption data were fitted by the Langmuir [35] and Freundlich [36] models, which can be expressed as Eqs. (7) and (8), respectively:

$$
\begin{aligned}
& q_{\mathrm{e}}=\frac{q_{\mathrm{m}} K_{\mathrm{L}} C_{\mathrm{e}}}{1+K_{\mathrm{L}} C_{\mathrm{e}}} \\
& q_{\mathrm{e}}=K_{\mathrm{F}} C_{\mathrm{e}}^{1 / \mathrm{n}}
\end{aligned}
$$

...where $q_{\mathrm{e}}$ and $q_{\mathrm{m}}(\mathrm{mg} / \mathrm{g})$ are the equilibrium and theoretical maximum adsorption capacities, respectively, $C_{\mathrm{e}}$ is the $\mathrm{RhB}$ concentration at equilibrium $(\mathrm{mg} / \mathrm{L}), K_{L}$ is the adsorption equilibrium constant of the Langmuir model $(\mathrm{L} / \mathrm{mg}), K_{F}$ is the adsorption capacity parameter of the Freundlich model, and $1 / n$ is the index of the Freundlich model.

The adsorption isotherms of RhB onto GMB600 are displayed in Fig. 5 and the relevant fitting parameters are presented in Table 3. It could be seen that the Freundlich model could fit the adsorption data better than the Langmuir model with the $R^{2}$ values above 0.986, indicating that the adsorption of $\mathrm{RhB}$ onto GMB600 was multilayer adsorption. Generally, the constant $K_{F}$ was positively related to the adsorption capacity. In this study, $K_{F}$ increased with the increase of temperature, indicating that the rise of temperature 


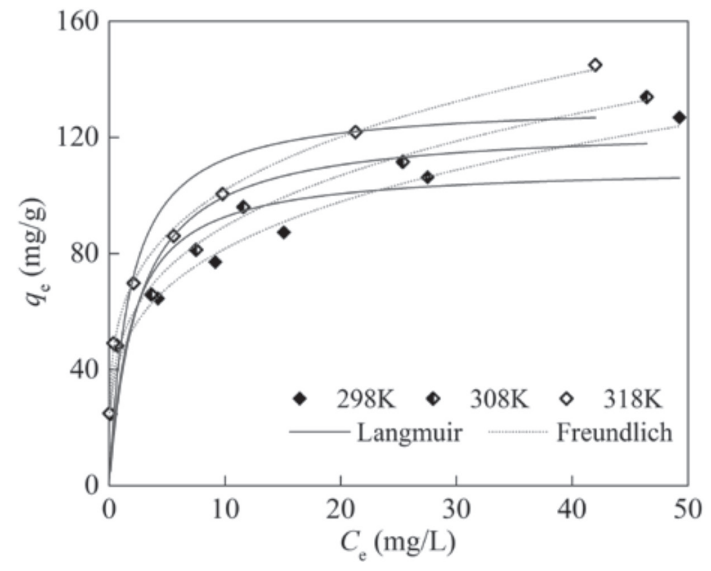

Fig. 5. Isotherm fitting curves of $\mathrm{RhB}$ adsorption onto GMB600.

could improve adsorption capacity. The constant $1 / n$ was positively related to surface homogeneity. The adsorption was difficult to happen if the $1 / n$ was greater than 1.0, while it was relatively easy to happen if the $1 / n$ was less than 0.5 [37]. In this study, the values of $1 / n$ were all lower than 0.3 , indicating that the $\mathrm{RhB}$ could be easily adsorbed by GMB600. In addition, the value of $1 / n$ decreased with the increase of temperature, indicating that the rise of temperature could make the adsorption happen more easily.

Table 4 showed the $K_{\mathrm{F}}$ values of different adsorbents for the $\mathrm{RhB}$ adsorption process. As seen, there are significant differences in the $K_{\mathrm{F}}$ values when different adsorbents adsorbed the same dye. The $K_{\mathrm{F}}$ values in this study were much higher than for other adsorbents, indicating that GMB600 had stronger adsorption capacity for RhB than other adsorbents. GMB600 has great potential application in the elimination of $\mathrm{RhB}$.

\section{Adsorption Thermodynamics}

Thermodynamic parameters such as Gibbs free energy change $\left(\Delta G^{\circ}\right)$, enthalpy change $\left(\Delta H^{\circ}\right)$ and entropy change $\left(\Delta S^{\circ}\right)$ for RhB adsorption onto GMB600 were calculated as Eqs. (9) and (10):

$$
\begin{gathered}
\Delta G^{\circ}=-R T \ln K_{\mathrm{d}} \\
\Delta G^{\circ}=\Delta H^{\circ}-T \Delta S^{\circ}
\end{gathered}
$$

...where $R$ is the ideal gas constant $(8.314 \mathrm{~J} /(\mathrm{mol} \cdot \mathrm{K}))$, $T$ is the Kelvin temperature $(\mathrm{K}), \Delta G^{\circ}$ is the Gibbs free energy change $(\mathrm{kJ} / \mathrm{mol}), \Delta H^{\circ}$ is the enthalpy change $(\mathrm{kJ} / \mathrm{mol}), \Delta S^{\circ}$ is the entropy change $(\mathrm{kJ} /(\mathrm{mol} \cdot \mathrm{K}))$, and $K_{d}$ is the thermodynamic equilibrium constant.

The calculation results are illustrated in Table 5 . The negative values of $\Delta G^{\circ}$ implied that the adsorption process of RhB onto GMB600 was spontaneous [43]. The decrease of $\Delta G^{\circ}$ as temperature increased indicated that high temperature could promote the spontaneous trend of adsorption, which is consistent with the previous results obtained from the Freundlich model. The positive value of $\Delta H^{\circ}(22.5519 \mathrm{~kJ} / \mathrm{mol})$ revealed that the adsorption would be an endothermic process [44]. According to previous studies $[45,46]$, the adsorption process was generally considered as chemical adsorption if $\Delta H^{\circ}>40 \mathrm{~kJ} / \mathrm{mol}$ or physical adsorption if $\Delta H^{\circ}<25 \mathrm{~kJ} / \mathrm{mol}$. Thus, the $\mathrm{RhB}$ adsorption onto GMB600 was primarily physical process. As reported by Tan et al. [47], the dominant force of adsorption was van der Waals forces if $\Delta H^{\circ}$ ranged from 4 to $10 \mathrm{~kJ} / \mathrm{mol}$, hydrogen bonding force if $\Delta H^{\circ}$ ranged from 2 to $40 \mathrm{~kJ} / \mathrm{mol}$ and dipole bonding force if $\Delta H^{\circ}$ ranged from 2 to $29 \mathrm{~kJ} / \mathrm{mol}$. Therefore, it could be speculated

Table 3. Fitting parameters of isotherm models for RhB adsorption onto GMB600.

\begin{tabular}{|c|c|c|c|c|c|c|}
\hline \multirow{2}{*}{$T(\mathrm{~K})$} & \multicolumn{3}{|c|}{ Langmuir model } & \multicolumn{3}{c|}{ Freundlich model } \\
\cline { 2 - 7 } & $q_{\mathrm{m}}$ & $K_{\mathrm{L}}$ & $R^{2}$ & $K_{\mathrm{F}}$ & $1 / n$ & $R^{2}$ \\
\hline 298 & 110.078 & 0.5284 & 0.7524 & 44.697 & 0.2615 & 0.9864 \\
\hline 308 & 124.072 & 0.4071 & 0.7920 & 49.272 & 0.2585 & 0.9919 \\
\hline 318 & 132.034 & 0.5723 & 0.7801 & 58.872 & 0.2382 & 0.9979 \\
\hline
\end{tabular}

Table 4. $K_{\mathrm{F}}$ values of different adsorbents for the $\mathrm{RhB}$ adsorption process.

\begin{tabular}{|c|c|c|}
\hline Adsorbent & $K_{\mathrm{F}}$ & References \\
\hline Beta zeolites & 2.54 & CHENG et al. [38] \\
\hline Pongamia glabra seed cover biochar & 4.653 & BORDOLOI et al. [39] \\
\hline Cotton stalks-activated carbon & 6.096 & ÖZDEMIR et al. [40] \\
\hline Chicken bone-based biochar & $2.98 \sim 6.23$ & OLADIPO et al. [41] \\
\hline Earthworm manure derived biochar & $2.53 \sim 8.70$ & WANG et al. [42] \\
\hline GMB600 & $44.697 \sim 58.872$ & This study \\
\hline
\end{tabular}


Table 5. Thermodynamic parameters of RhB adsorption onto GMB600.

\begin{tabular}{|c|c|c|c|c|c|}
\hline$T(\mathrm{~K})$ & $K_{d}$ & $\Delta G^{\circ}$ & $\Delta H^{\circ}$ & $\Delta S^{\circ}$ & $R^{2}$ \\
\hline 298 & 5.783 & -4.348 & 22.5519 & 0.0904 & 0.9787 \\
\hline
\end{tabular}

that the adsorption of $\mathrm{RhB}$ onto GMB600 primarily involved a hydrogen and/or dipole bonding force. The positive value of $\Delta S^{\circ}(0.0904 \mathrm{~kJ} /(\mathrm{mol} \cdot \mathrm{K}))$ indicated that the adsorption was a process of entropy increase. In this process, the order degree of the solid-liquid interface decreased [48].

\section{FTIR Analysis Before and After Adsorption}

To further analyze the adsorption mechanism, the infrared spectrum analysis was conducted to identify the functional groups on the surface of GMB600 before and after adsorption, and the results are presented in Fig. 6.

As observed from Fig. 6, the GMB600 before adsorption contained a number of oxygen-containing groups such as hydroxy, carbonyl and ester, which provided favorable conditions for the adsorption of RhB. The adsorption peaks at 3673, 1574, 1047 and $794 \mathrm{~cm}^{-1}$ were attributed to the stretching vibration of hydroxyl proups $(-\mathrm{OH})$, the bending vibration of $\mathrm{C}=\mathrm{C}$ and $\mathrm{C}=\mathrm{O}$ in aromatic, the stretching vibration of $\mathrm{C}-\mathrm{O}$ in esters and ethers, and the bending vibration of $\mathrm{C}-\mathrm{H}$ in aromatic and heterocyclic [49], respectively.

After the adsorption of $\mathrm{RhB}$, several new peaks appeared at $3020 \sim 3384$ and $1401 \mathrm{~cm}^{-1}$, which were the adsorption peaks of $-\mathrm{OH}$ and $\mathrm{C}-\mathrm{H}$, respectively. The adsorption peak of $\mathrm{C}-\mathrm{O}$ shifted to $1062 \mathrm{~cm}^{-1}$, indicating that $\mathrm{C}-\mathrm{O}$ was involved in the adsorption process of $\mathrm{RhB}$ onto GMB600. The adsorption peak of $-\mathrm{OH}$ shifted to $3686 \mathrm{~cm}^{-1}$, suggesting that the hydrogen bond might be formed via the combination of $-\mathrm{CH}_{3},-\mathrm{COOH}$ in

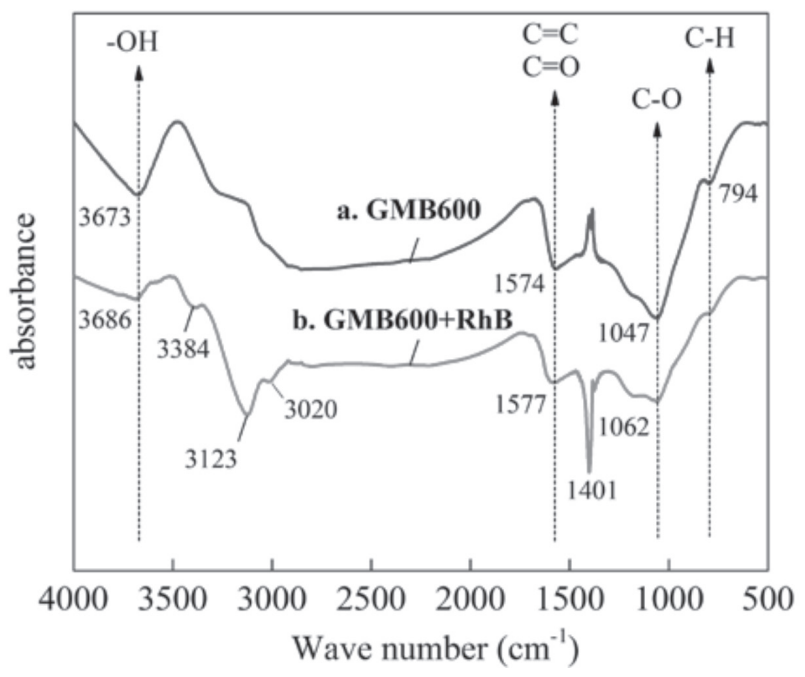

Fig. 6. FTIR spectra before a. and after b. RhB adsorption by GMB600.
$\mathrm{RhB}$ and the oxygen-containing functional groups on GMB600. Therefore, the hydrogen bond played an important role in the adsorption process, which was in agreement with the result of the above thermodynamic analysis [50]. Meanwhile, the adsorption peak at $1574 \mathrm{~cm}^{-1}$ shifted to $1577 \mathrm{~cm}^{-1}$ and the adsorption peak at $794 \mathrm{~cm}^{-1}$ disappeared. This may be associated with the $\pi-\pi$ bond formed via the combination of $\pi$ electron acceptor $(-\mathrm{COOH})$ in $\mathrm{RhB}$ and $\pi$ electron donors $(\mathrm{C}=\mathrm{C}$, $\mathrm{C}-\mathrm{H})$ on GMB600 [51]. Thus, the $\pi-\pi$ bond was also of great significance to the adsorption of $\mathrm{RhB}$ onto GMB600.

\section{Conclusions}

In the present study, the biochar prepared by goat manure at $600^{\circ} \mathrm{C}$ was found to be a potential adsorbent for the removal of $\mathrm{RhB}$ from aqueous solution. The $\mathrm{RhB}$ was optimally adsorbed at $\mathrm{pH}$ 5.0, GMB600 dosage $0.4 \mathrm{~g} / \mathrm{L}$ and contact time for $150 \mathrm{~min}$ when initial $\mathrm{RhB}$ concentration was $20 \mathrm{mg} / \mathrm{L}$ and temperature was $25^{\circ} \mathrm{C}$. The adsorption process of $\mathrm{RhB}$ onto GMB600 was found to obey the pseudo second-order model and the Freundlich model well. The fitting results showed that the intra-particle diffusion was not the only limiting step, liquid film diffusion and surface adsorption may also regulate the adsorption rate. The thermodynamic study showed that the adsorption of RhB onto GMB600 was a spontaneous, endothermic and entropy-increasing process. According to the FTIR analysis, the adsorption of RhB onto GMB600 was closely related to the effect of hydrogen bond and $\pi-\pi$ bond.

\section{Acknowledgments}

This study was financially supported by the Center of Big Data for Smart Environmental Protection, Sichuan Science and Technology Program (No. 2019JDRC0136), a CDTU Laboratory Open Fund Project (No. 2018SJ09) and a project of the university level in CDTU (No. 2018ZR004, 2019RC009).

\section{Conflict of Interest}

The authors declare no conflict of interest.

\section{References}

1. NAN L., ZHAO Y., LIU H., GUO Y., XING Y., HUI X., PENG H., QIN H. Design of polyoxometallate-titania 
composite film $\left(\mathrm{H}_{3} \mathrm{PW}_{12} \mathrm{O}_{40} / \mathrm{TiO}_{2}\right)$ for the degradation of an aqueous dye Rhodamine $\mathrm{B}$ under the simulated sunlight irradiation. Journal of Hazardous Materials, 199, 1, 2012.

2. SHEN J., WU Y., ZHANG B., LI F. Adsorption of Rhodamine $\mathrm{B}$ dye by biomimetic mesoporous $\mathrm{SiO}_{2}$ nanosheets. Technologies and Environmental Policy, 17, 2289, 2015.

3. KOOH M.R.R., LIM L.B.L., LIM L.H., DAHRI M.K. Separation of toxic rhodamine B from aqueous solution using an efficient low-cost material, Azolla pinnata, by adsorption method. Environmental Monitoring and Assessment, 188, 108, 2016.

4. KORNBRUST D., BARFKNECHT T. Testing of 24 food, drug, cosmetic, and fabric dyes in the in vitro and the in vivo/in vitro rat hepatocyte primary culture/DNA repair assays. Environmental \& Molecular Mutagenesis, 7, 101, 2010.

5. SU X., LI X., LI J., LIU M., LEI F., TAN X., LI P., LUO W. Synthesis and characterization of core-shell magnetic molecularly imprinted polymers for solid-phase extraction and determination of Rhodamine $\mathrm{B}$ in food. Food Chemistry, 171, 292, 2015.

6. JIANG X., HUANG J. Adsorption of Rhodamine B on two novel polar-modified post-cross-linked resins: Equilibrium and kinetics. Journal of Colloid and Interface Science, 467, 230, 2016.

7. KOOH M.R.R., DAHRI M.K., LIM L.B. The removal of rhodamine $\mathrm{B}$ dye from aqueous solution using Casuarina equisetifolia needles as adsorbent. Cogent environmental science, 2, 1140553, 2016.

8. TIAN J., OLAJUYIN A. M., MU T., YANG M., XING J. Efficient degradation of rhodamine B using modified graphite felt gas diffusion electrode by electro-Fenton process. Environmental Science and Pollution Research, 23, 11574, 2016.

9. WANG Q., LI J., BAI Y., LU X., DING Y., YIN S., HUANG H., MA H., WANG F., SU B. Photodegradation of textile dye Rhodamine B over a novel biopolymer-metal complex wool-Pd/CdS photocatalysts under visible light irradiation. Journal of Photochemistry Photobiology B: Biology, 126, 47, 2013.

10. KURUKUTLA A.B., KUMAR P.S.S., ANANDAN S., SIVASANKAR T. Sonochemical degradation of Rhodamine B using oxidants, hydrogen peroxide/ peroxydisulfate/peroxymonosulfate, with $\mathrm{Fe}^{2+}$ ion: proposed pathway and kinetics. Environmental Engineering Science, 32, 129, 2015.

11. BASLAK C., ARSLAN G., KUS M., CENGELOGLU Y. Removal of Rhodamine B from water by using CdTeSe quantum dot-cellulose membrane composites. Rsc Advances, 6, 18549, 2016.

12. DONG W., LI W., WANG G., CHEN K., LU L., QIN H. Adsorption and heterogeneous degradation of rhodamine $\mathrm{B}$ on the surface of magnetic bentonite material. Applied Surface Science, 349, 988, 2015.

13. MA L., XI Y., HE H., AYOKO G.A., ZHU R., ZHU J. Efficiency of Fe-montmorillonite on the removal of Rhodamine B and hexavalent chromium from aqueous solution. Applied Clay Science, 120, 9, 2016.

14. DING L., BO Z., WEI G., QI L.,WANG Z., GUO Y., WANG X., LIU Y. Adsorption of Rhodamine-B from aqueous solution using treated rice husk-based activated carbon. Colloids and Surfaces a-Physicochemical and Engineering Aspects, 446, 1, 2014.

15. KHAN T.A., NAZIR M., KHAN E.A. Adsorptive removal of rhodamine $\mathrm{B}$ from textile wastewater using water chestnut (Trapa natans L.) peel: adsorption dynamics and kinetic studies. Toxicological and Environmental Chemistry, 95, 919, 2013.

16. THEIVARASU C., MYLSAMY S. Equilibrium and kinetic adsorption studies of Rhodamine-B from aqueous solutions using cocoa (Theobroma cacao) shell as a new adsorbent. International Journal of Engineering Science \& Technology, 2, 6284, 2010.

17. ZWIETEN L.V., KIMBER S., MORRIS S., CHAN K.Y., DOWNIE A., RUST J., JOSEPH S., COWIE A. Effects of biochar from slow pyrolysis of papermill waste on agronomic performance and soil fertility. Plant and Soil, 327, 235, 2010.

18. SAIFURREHMAN M., ILGOOK K., RASHID N., UMER M.A., SAJID M., HAN J.I. Adsorption of brilliant green dye on biochar prepared from lignocellulosic bioethanol plant waste. Clean-Soil Air Water, 44, 55, 2016.

19. TAN Z., LIN C.S., JI X., RAINEY T.J. Returning biochar to fields: a review. Applied Soil Ecology, 116, 1, 2017.

20. JANG J., MIRAN W., DIVINE S.D., NAWAZ M., SHAHZAD A., WOO S.H., LEE D.S. Rice straw-based biochar beads for the removal of radioactive strontium from aqueous solution. Science of the Total Environment, 615, 698, 2018.

21. LIAN F., CUI G., LIU Z., LIAN D., ZHANG G., XING B. One-step synthesis of a novel N-doped microporous biochar derived from crop straws with high dye adsorption capacity. Journal of Environmental Management, 176, 61, 2016.

22. SUN L., WAN S., LUO W. Biochars prepared from anaerobic digestion residue, palm bark, and eucalyptus for adsorption of cationic methylene blue dye: Characterization, equilibrium, and kinetic studies. Bioresource Technology, 140, 406, 2013.

23. XU Y., LIU Y., LIU S., TAN X., ZENG G., ZENG W., DING Y., CAO W., ZHENG B. Enhanced adsorption of methylene blue by citric acid modification of biochar derived from water hyacinth (Eichornia crassipes). Environmental Science and Pollution Research, 23, 1, 2016.

24. SCHIMMELPFENNIG S., GLASER B. One step forward toward characterization: some important material properties to distinguish biochars. Journal of Environmental Quality, 41, 1001, 2012.

25. SPOKAS K.A. Review of the stability of biochar in soils: predictability of O:C molar ratios. Carbon Management, 1, 289, 2010.

26. DESHPANDE APARNA V., KUMAR UDAY. Effect of method of preparation on photophysical properties of $\mathrm{Rh}-\mathrm{B}$ impregnated sol-gel hosts. Journal of Non-Crystalline Solids, 306, 149, 2002.

27. LI L., LIU S., ZHU T. Application of activated carbon derived from scrap tires for adsorption of Rhodamine B. Journal of Environmental Sciences, 22, 1273, 2010.

28. GUO Y., ZHAO J., HUI Z., YANG S., QI J., WANG Z., $\mathrm{XU} \mathrm{H}$. Use of rice husk-based porous carbon for adsorption of Rhodamine B from aqueous solutions. Dyes Pigments, 66, 123, 2005 .

29. ALJEBOREE A.M., ALKAIM A.F., AL-DUJAILI A.H. Adsorption isotherm, kinetic modeling and thermodynamics of crystal violet dye on coconut huskbased activated carbon. Desalination Water Treatment, 53, 3656, 2015.

30. LAGERGREN S.K. About the theory of so-called adsorption of soluble substances. Sven. Vetenskapsakad. Handingarl, 24, 1, 1898. 
31. HO Y., MCKAY G. Sorption of dye from aqueous solution by peat. Chemical Engineering Journal, 70, 115, 1998.

32. WEBER W.J., MORRIS J.C. Kinetics of adsorption on carbon from solution. Journal of the Sanitary Engineering Division, 89, 31, 1963.

33. WU F., TSENG R., JUANG R. Characteristics of Elovich equation used for the analysis of adsorption kinetics in dye-chitosan systems. Chemical Engineering Journal,150, 366, 2009.

34. YUH-SHAN H. Review of second-order models for adsorption systems. Cheminform,136, 681, 2006.

35. LANGMUIR I. The constitution and fundamental properties of solids and liquids. Part I. Solids. Journal of the American Chemical Society, 38, 2221, 1916.

36. FREUNDLICH H. Over the adsorption in solution. Journal of Physical Chemistry, 57, 1100, 1906.

37. NAMASIVAYAM C., KAVITHA D. Removal of Congo Red from water by adsorption onto activated carbon prepared from coir pith, an agricultural solid waste. Dyes Pigments, 54, 47, 2002.

38. CHENG Z.L., LI Y.X., LIU Z. Study on adsorption of rhodamine $\mathrm{B}$ onto Beta zeolites by tuning $\mathrm{SiO}_{2} / \mathrm{Al}_{2} \mathrm{O}_{3}$ ratio. Ecotoxicology and Environmental Safety, 148, 585, 2017.

39. BORDOLOI N., DEY M.D., MUKHOPADHYAY R., KATAKI R. Adsorption of Methylene blue and Rhodamine B by using biochar derived from Pongamia glabra seed cover. Water Science Technology, 77, wst2017579, 2018.

40. ÖZDEMIR M., DURMUŞ Ö., ŞAHIN Ö., SAKA C. Removal of methylene blue, methyl violet, rhodamine B, alizarin red, and bromocresol green dyes from aqueous solutions on activated cotton stalks. Desalination Water Treatment, 57, 1, 2015.

41. OLADIPO A.A., IFEBAJO A.O., NISAR N., AJAYI O.A. High-performance magnetic chicken bone-based biochar for efficient removal of rhodamine-B dye and tetracycline: competitive sorption analysis. Water Science Technology, 76, 373, 2017.

42. WANG Z., SHEN D., FEI S., WU C., GU S. Kinetics, equilibrium and thermodynamics studies on biosorption of Rhodamine B from aqueous solution by earthworm manure derived biochar. International Biodeterioration Biodegradation, 120, 104, 2017.

43. ZOU W., KE L., BAI H., SHI X., HAN R. Enhanced cationic dyes removal from aqueous solution by oxalic acid modified rice husk. Journal of Chemical Engineering Data, 56, 1882, 2011

44. FENG D., YU H., DENG H., LI F., GE C. Adsorption characteristics of norfloxacin by biochar prepared by cassava dreg: Kinetics, isotherms, and thermodynamic analysis. BioResources, 10, 6751, 2015.

45. SUÁREZGARCíA F.N., MARTíNEZALONSO A., TASCÓN J. Activated carbon fibers from Nomex by chemical activation with phosphoric acid. Carbon, 42, 1419, 2004.

46. GUPTA V.K., PATHANIA D., SHARMA S., SINGH P. Preparation of bio-based porous carbon by microwave assisted phosphoric acid activation and its use for adsorption of $\mathrm{Cr}(\mathrm{VI})$. Journal of Colloid Interface Science, 401, 125, 2013.

47. WEI T., LI G., MEI B., MIN Y., PENG J., BARROW C.J., YANG W., WANG H. The study of adsorption mechanism of mixed pesticides prometryne-acetochlor in the soil-water system. International Biodeterioration Biodegradation, 102, 281, 2015.

48. WU Z., JOO H., LEE K. Kinetics and thermodynamics of the organic dye adsorption on the mesoporous hybrid xerogel. Chemical Engineering Journal, 112, 227, 2005.

49. STEINBEISS S., GLEIXNER G., ANTONIETTI M. Effect of biochar amendment on soil carbon balance and soil microbial activity. Soil Biology Biochemistry, 41, 1301, 2009.

50. TRIPATHI P.K., LIU M., XU Z., ZHU D., RAO N.N. High surface area ordered mesoporous carbon for high-level removal of rhodamine B. Journal of Materials Science, $\mathbf{4 8}$, 8003,2013

51. WU M., PAN B., ZHANG D., XIAO D., LI H., WANG C., NING P. The sorption of organic contaminants on biochars derived from sediments with high organic carbon content. Chemosphere, 90, 782, 2013. 